\title{
IMPROVING THE RESULTS OF STUDENTS FREE POETRY WRITING SKILLS USING STRATEGI TULIS KINI, DI SINI
}

\author{
Dwi Cahyadi Wibowo, Bety Nur Dwi Jayanti, Valentinus Ola Beding \\ STKIP Persada Khatulistiwa Sintang \\ dwicahyadiwibowo@gmail.com,betynurdwijayanti@gmail.com,valentinusolabeding@gmail.com
}

\begin{abstract}
The background of the problem in this study is the low interest of students in writing because they consider writing to be unpleasant, students' low understanding of the material, many students find it difficult to write free poetry, low strategies, models, or learning methods and learning media used by teachers less interesting and fun that makes students pay less attention to lessons while in class. The purpose of this study was to improve the improvement of poetry writing skills freely using the current writing strategy, here in class V B of State Elementary School 23 Clogging the 2018/2019 school year. The form of this research is classroom action research carried out in two cycles. Each cycle consists of four stages, namely planning, implementation, observation, and reflection. The subjects of the study were students of class V B of Elementary School 23 menyumbung which amounted to 23 students. Data sources came from class V B students, V B grade teachers, learning activities and documents. To collect data used observation sheets, test questions and student interview sheets. The results of class action research show that the current writing strategy, here can significantly improve students' free poetry writing skills. Student learning outcomes in the first cycle of all the questions given obtained an average value of 64.22. In the second cycle of the overall questions given an average value of 70.68 was obtained so that the average increase of 6.46 was obtained. And the students' response to the strategies used was easy to understand and fun. So it can be concluded that there was an increase in poetry writing skills. free to use the current write strategy, here.
\end{abstract}

Keywords: Writing Learning, Strategies Now, Here, Free Poetry Writing Skills

\section{INTRODUCTION}

Hamzah (2016: 1) states that Education is a system of educating children of the nation. Nowadays Education is now faced various problems; they are economic, social, cultural, and political. Through education human can develop their potential that the Indonesian standard of education is not left behind from the other nation, because the process of education is a process of learning and studying.

Learning to write poetry in school is part of learning to write literature. Emzir (2015) states that the purpose of teaching poetry is so that students gain more awareness of themselves, others and the surrounding environment and gain pleasure and basic knowledge of poetry. Therefore, poetry is very important to be noticed and given to students. Because at Indonesian language lessons, literature is including as an ingredient that must be taught to students in addition to other language skills.

The success of the implementation of Indonesian Language and Literature learning process was influenced on the creativity of teachers. SDN 23 Menyumbung, there are two classes which are class VA and V B, from that two classes, the VB class is one class that has an average that is quite low at writing poetry subject. That case can be seen from the result of the 
student test result, there are 16 students complete and 7 students do not complete from 23 students.

Based on the results of pre-observation, there are several students who did not completed writing skills due to several factors, they are lack of skills in writing, students' interest in writing is low because they think writing is unpleasant, lack of students' understanding of the material, many students often find it difficult to find strategies, models, or learning methods and learning media used by teachers is less attractive and enjoyable that made students did not interesting and less attention to the lessons while in class.

The using of the right strategy can achieve the desired learning goals. In the other words, the strategy can be used as a way of teaching teachers to carry out the learning process that will be implemented, so that the teacher can implement the learning process effectively. The strategy used is adjusted to the material taught and adapted to the conditions of students. Therefore, researchers and collaborators are agreed to try finding solutions to these problems. The solutions offered are the use of strategies that can attract students' attention and explore the potential of students in writing poetry.

The using of appropriate learning strategies can be an alternative in the learning process which will make the learning process more varied so that it did not bored students. The strategy used is the strategi tulis kini, di sini. Silberman (2016: 198) states that the current writing strategy is a dramatic way to increase self-reflection is to ask students to write current actions about an experience they have. Strategi tulis kini, di sini was become an active learning according to Hamdani (2011: 48) active learning is a teaching and learning strategy that aims to improve the quality of education.

The Strategi tulis kini, di sini can make students interested in learning. Even more than that, students are expected to be happy and have more interest so that students' ability to write free poetry can improve better. Strategi tulis kini, di sini was expected to be effective in learning the skills of SDN 23 Menyumbung in writing poetry.

\section{METHOD}

The approach in this study was descriptive qualitative research. The reason that using descriptive research with a qualitative approach was due to raising facts that occur in the field, and representing the truth about the fact. The research method used in this study was a qualitative research method with a descriptive approach. The research form used class action research.

This research was carried out in the SDN 23 Menyumbung Kecamatan Sintang. The subject of this research was Kelas V B SDN 23 Menyumbung. The research subjects were 23 
students in kelas V B. The research used two sources, they are primary data source that consist of and the second sources were (a) the results of strategic observations from Strategi tulis kini, di sini, and (b) the value of student tests in working on problems in each cycle.

Data collection techniques used in this study were direct observation, measurement, direct communication, and documentation. While the data collection tools used in this study were observation sheets, test questions, interview sheets, and documents. In this study researcher was validated the data using data triangulation. The validity test of the data used a technique proposed by Miles and Huberman (Sugiyono 2008: 246) the stages of validity data collection, data reduction, data display and conclusion / verification.

\section{FINDING AND DISCUSSION}

Based on the analysis of the data obtained the following results

(1) Implementation of Learning Using the Strategi tulis kini, di sini.

a. Teacher Observation

The data from the teacher's observation while teaching using Strategi tulis kini, di sini can be seen in table 1.

Table1. Teacher Observation Result

\begin{tabular}{|c|c|c|c|c|c|c|}
\hline \multirow{2}{*}{ No } & \multirow{2}{*}{ Cycle } & \multirow{2}{*}{ Meeting } & \multicolumn{2}{|c|}{ Answer } & \multirow{2}{*}{$\%$} & \multirow{2}{*}{ Information } \\
\cline { 3 - 6 } & & & Yes & No & & Very Good \\
\hline 1 & I & 1 & 21 & 2 & 91 & Very Good \\
\hline 2 & I & 2 & 22 & 1 & 96 & Very Good \\
\hline 3 & II & 1 & 22 & 1 & 96 & Very Good \\
\hline 4 & II & 2 & 23 & 0 & 100 & \\
\hline
\end{tabular}

In the cycle I of meeting got the result based on observer's observation by answering "Yes" were 21 if presented at 91\% and the answer "No" were 2 if presented at $8 \%$. In cycle I of meeting II got the result based on observer's observation by answering "Yes" were 22 if presented at 96\% and the answer "No" were 1 if presented at $4 \%$. In cycle II of meeting I got the result observer's observation by answering "Yes" were 22 if presented at $96 \%$ and the answer "No" was 1 if presented at $4 \%$. In cycle II of meeting II got the result based on observer's observation by answering "Yes" were 23 if presented at $100 \%$ and the answer "No" was 0 if presented at $0 \%$.

Based on the description above shows that the teacher's activities in carrying out learning using Strategi tulis kini, di sini on free poetry material in class V B students of Sekolah Dasar Negeri 23 Menyumbung got a very significant increase and can be said to be very good. 
a. Student Observation

Data from the observation of students at the time of learning using Strategi tulis kini, di sini, on free poetry material, can be seen in table 2 as follows.

Table 2. Data of Students Observation Results

\begin{tabular}{|c|c|c|c|c|c|c|}
\hline \multirow{2}{*}{ No } & \multirow{2}{*}{ Cycle } & \multirow{2}{*}{ Meeting } & \multicolumn{2}{|c|}{ Answer } & \multirow{2}{*}{ Information } \\
\cline { 3 - 6 } & & & Yes & No & \\
\hline 1 & I & 1 & 20 & 3 & 86 & Very Good \\
\hline 2 & I & 2 & 21 & 2 & 91 & Very Good \\
\hline 3 & II & 1 & 22 & 1 & 96 & Very Good \\
\hline 4 & II & 2 & 23 & 0 & 100 & Very Good \\
\hline
\end{tabular}

Based on observations made by observers in meeting 1 of the first cycle, obtained observers observations by answering "Yes" was 20 if presented were $86 \%$ and answered "No" was 3 if presented was 13\%. Answer "Yes" was 21 if presented was $91 \%$ and answer "No" was 2 if presented was $8 \%$.

Meeting 1 was Cycle II was obtained by observers' observations by answering "Yes" was 22 if presented was 96\% and answering "No" was 1 if presented was 4\%. In the meeting 2 of second cycle the observers obtained the results of observations by answering "Yes" was 23 if presented was $100 \%$ and answered "No" was 0 if presented was $0 \%$.

Based on the analysis above, it can be seen that the activities of students when learning using (writing now, here) strategy in the free poetry material increased from the first cycle of the presented was $90 \%$, in the second cycle it increased to $100 \%$ which was very significant and could be said to be very good. And the researchers decided to stop the research.

(1) Improving the Results of Students Free Poetry Writing Skills Using Strategi tulis kini, di sini..

Improving learning outcomes in the first cycle can be seen in the value of student test results after the teacher applied the Strategi tulis kini, di sini, in the teaching and learning process. In the first cycle phase, obtained from 23 students who took the test, only 12 students completed and those who did not complete 11 people, the value obtained in the first cycle with the highest score was 94 and the lowest score was 40 . The average value of all students is 64.22 with sufficient category, classical completeness of $52.17 \%$ at this stage the achievements obtained have not reached 
classical completeness, which is $<75 \%$ of the number of students who get 65 according to the specified KKM. From the analysis of learning outcomes in the first cycle, the researcher decided to proceed to the next stage, namely the second cycle in the hope that the results obtained could reach the expected completeness.

Cycle II stage of student learning outcomes obtained has increased, namely by increasing the completeness of student learning outcomes from 23 students who took the complete test was 19 students, the value obtained in the second cycle with the highest score was 97 and the lowest value was 42, the value average was $70.68 \%$ and classical completeness was $82.62 \%$, so that the achievement completeness in the second cycle was declared successful because of the classical completeness data obtained $<75 \%$ of the number of students who obtained a score of 65 according to the determined $\mathrm{KKM}$, the researchers decided not continue the next cycle.

Based on the results of the tests conducted in the first cycle and second cycle, an increase in free poetry writing skills of students using the Strategi tulis kini, di sini, on Indonesian language subjects in V B class of Sekolah Dasar Negeri 23 Menyumbung. Data on increasing learning outcomes of cycle I and cycle II can be seen in Table 4.3 as follows:

Table 3. Improvement Result of Writing Poem Skill in Cycle 1 and Cycle II

\begin{tabular}{|l|l|l|l|}
\hline No & The Test Result & Cycle I & Cycle II \\
\hline 1 & The Highest Score & 94 & 97 \\
\hline 2 & The Lowest Score & 40 & 42 \\
\hline 3 & Success & 12 Students & 19 Students \\
\hline 4 & Failed & 11 Students & 4 Students \\
\hline 5 & Average Score & 64,22 & 70,68 \\
\hline 6 & Classical Completeness & 52,17 & 82,60 \\
\hline 7 & Improvement of Average Score on Cycle I and Cycle II & & 6,46 \\
\hline 8 & Improvement of Classical Completeness on Cycle I and Cycle II & & 30,43 \\
\hline
\end{tabular}

Based on the comparison of the results of students writing free poetry by using (writing strategy now, here) which has been described in the first cycle with the number of students 23 people, students who pass was 12 peoples and students who did not pass was 11 peoples. Whereas in the second cycle with the same number of students, that was 23 people, students who pass was 19 peoples and students who did not pass was 4 people. Thus the researchers decided to stop their research in the second cycle.

From the results presented, the discussion is presented as follows: 
(1) The use (Current Writing Strategy, Here) in free poetry writing learning for Indonesian Language Subjects in V B Class of Sekolah Dasar Negeri 23

Menyumbung in academic year 2018/2019.

Silberman (2016: 198) declares (a modern writing strategy, here) is a dramatic way to increase contemplation independently is to ask students about the current experience they need. Strategi tulis kini, di sini, that is used in free writing learning to improve learning, and results tests of class V B.

It can be seen from the observation data in the first cycle, the teacher has not mastered the class, so the students are still noisy in the first cycle, reflection for the second cycle, then Cycle II is the process of improving the learning cycle I, so that it impacts on student learning outcomes.

Learning with (present writing strategy, here) in the class during the first and second cycles, is shown by raising the enthusiasm of students, such as presenting a poem, giving questions that can arouse students' imagination and discuss examples of poems that are shared with students. Providing guidance students safely and comfortably. Stimulated students to be able to speak in front of friends, and can writing poetry based on to the students' imagination. So that there are results of student writing that are not in accordance with the questions submitted by the teacher when learning takes place.

This was because the teacher did not force students to write poetry in accordance with the questions the teacher presented; these questions were only to help students' imagination to develop more, because not all students have innate skills in writing. Therefore researchers and teachers used Strategi tulis kini, di sini to awaken and growth the imagination of students to be more creative and imaginative in writing poetry.

(1) Improving of free poetry writing skill by using on Indonesian Language Subjects in V B Class of Sekolah Dasar Negeri 23 Menyumbung in academic year 2018/2019.

Pradopo (2012: 14) states that writing poetry is the most complex skill, because poetry writing skills are a developmental process that requires experience, time, agreement, practice and requires a regular way of thinking to express ideas in written language. 
Based on student evaluation value data in the first cycle seen from the number of students who passed and have not been passed, then the average value obtained was 64.22 and classical learning completeness was $52.17 \%$. The details of the assessment criteria for writing poetry in the first cycle, namely aspects of the assessment of the meaning of meaning between lines and stanzas which included very good category was 8 students (34.78\%), good category was 5 students $(21.73 \%)$, fair category was 8 students (17.64\%), and poor category was 2 students (86.95\%). The second aspect was the suitability of the title and theme with the content, very good category was 4 students (17.29\%), the good category was 10 students $(43.47 \%)$, the fairly good category 7 students $(30.43 \%)$, and the poor category 2 students $(86.95 \%)$. The third aspect is diction, very good category 3 students (13.04\%), good category 4 students (17.39\%), quite good category 6 students (26.08\%), and less 10 students (43.47\%). The fourth aspect was language style, very good category 3 students (13.04\%), good category were 3 students (13.04\%), fair good category was 9 students (39.13\%), and fewer categories was 8 students $(17.64 \%)$. The fifth aspect was imagination, excellent category was 0 students, good category was 6 students (26.08\%), fair category was 9 students $(39.13 \%)$ and poor category was 8 students $(34.78 \%)$. The sixth aspect was rhyme, very good category was 1 student (43.47\%), good category was 4 students (17.39\%), fair category was 10 students (43.47\%), and poor category was 8 students (17.64\%) And the seventh aspect was mandate, excellent category was 3 students (13.04\%),good category was 7 students $(30.43 \%)$, fair category was 6 students $(26.08 \%)$ and poor category was 7 students $(2608 \%)$.

Based on the data of of student' evaluation score in cycle II seen from the number of students who completed and have not been completed, then the average value obtained at 70.68 and classical learning completeness increased to $82.60 \%$. The details of the assessment criteria for writing poetry in cycle II could be seen from the aspects of assessment. Details of the assessment criteria for writing poetry in the second cycle were: the first aspect was meaning integreated assessment between lines and sections included in the excellent category there were 15 students $(65.21 \%)$, good category 6 students $(26.06 \%)$, good enough category 2 students $(86.95 \%)$, and poor category none. The second aspect was the suitability of the title and theme with the content, very good category 5 students $(21.73 \%)$, good category 16 students $(69.56 \%)$, quite good category 
1 student (43.47\%), and poor category 1 student (43.47\%). The third aspect was diction, very good category 1 student (43.47\%), good category 3 students (13.04\%), quite good category 16 students (69.56\%), and poor category 3 students (13.04\%) The fourth aspect was language style, very good category 2 students (86.95\%), good category 7 students $(30.43 \%)$, good enough category 12 students $(52.17 \%)$, and poor category 2 students (86.95\%). The fifth aspect was imagination, the excellent category of 2 students (86.95\%), the good category 4 students (17.39\%), the fairly good category 15 students $(65.21 \%)$ and the poor category 2 students $(86.95 \%)$. The sixth aspect was rhyme, very good category $3(13.04 \%)$, good category 6 students $(26.08 \%)$, good enough category 8 students $(34.78 \%)$, poor category 6 students (26.08\%) And the seventh aspects of the mandate, very good category 2 students (86.95\%), good category 4 students $(17.39 \%)$ quite good category 12 students $(52.17 \%)$ and poor category 5 students ( $21.73 \%)$

Based on the comparison score of cycles I and II, there were differences in the results of the mastery level was very good in the first cycle as many as 5 students while in the second cycle as many as 3 students.

The mastery level in the first cycle was 9 students, while in the second cycle there were 17 students. The mastery level was enough in the first cycle as many as 8 students, while in the second cycle there were 3 students. The mastery level was less in the first cycle as many as 1 student and in the second cycle there was no student at that level. The increase of average score in cycles I and II was 6.46, which is from 64.22 in the first cycle and 70.68 in the second cycle. Classical learning completeness has increased by $30.43 \%$, which was from $52.17 \%$ in the first cycle to $82.60 \%$ in the second cycle.

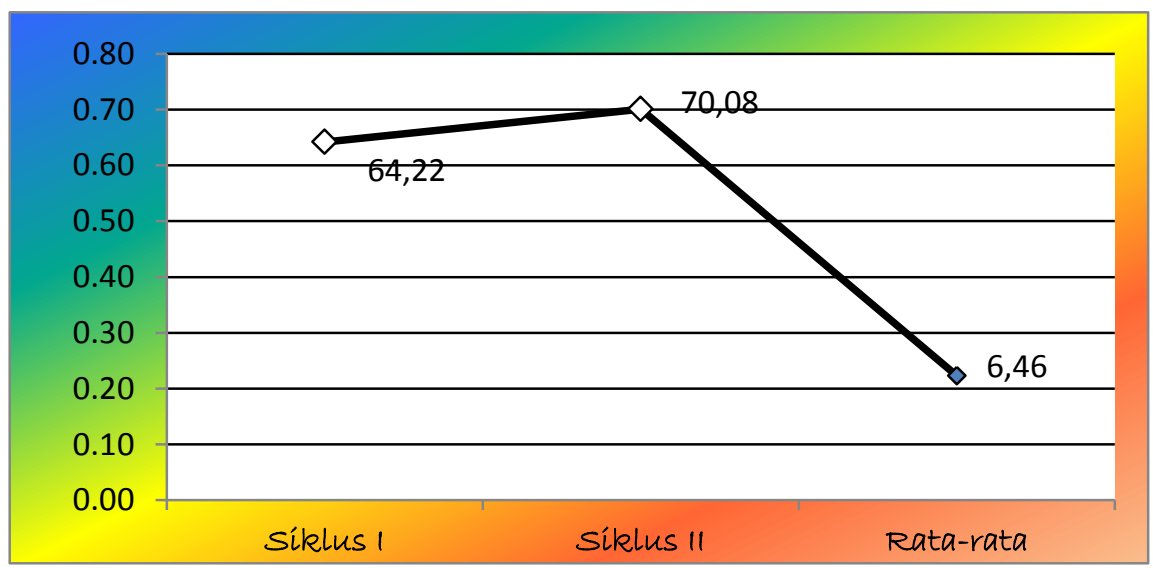


Chart 1 .The result of comparison of students' average score in cycle 1 and cycle 2

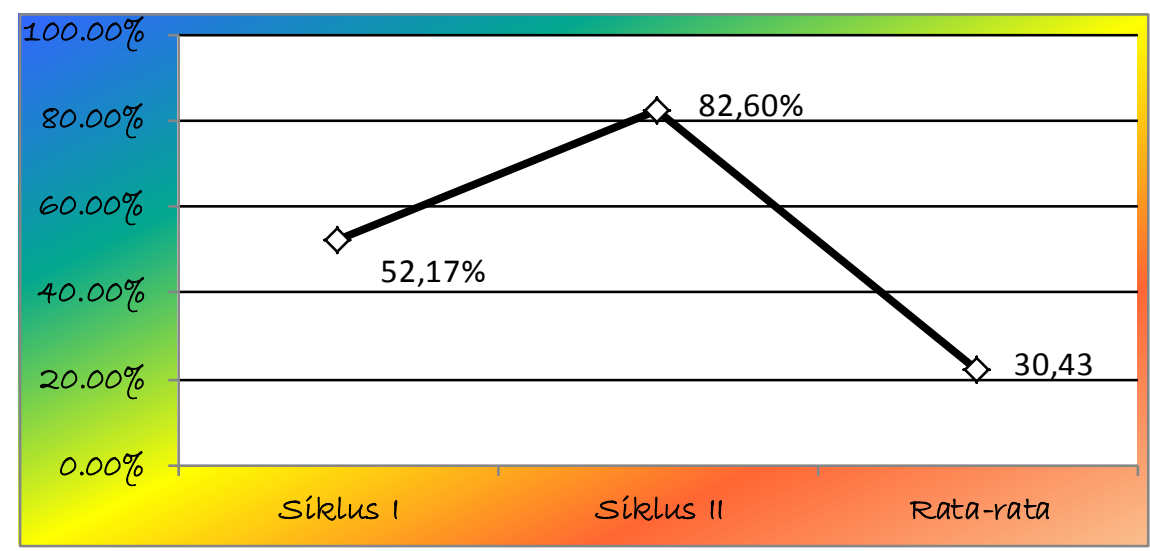

Chart 2. The Result of Classical Learning Completeness in cycle I and cycle II

(1) Students' responses toward the lesson of writing free poetry by using Strategi Tulis Kini on Bahasa Indonesia subject at clas VB SDN 23 Menyumbung, academic year $2018 / 2019$.

Silberman (2016: 198) states that the Strategi Tulis Kini, is a dramatic way to increase contemplation independently by asking for the students to write down current actions about an their experience. Learning to use these strategies can increase student' interest in writing by involving students' imagination related to experience, and train students to be active in learning by writing independently.

Based on the student interviews towards the lesson of writing free poetry by using Strategi Tulis Kini, It was getting good response, in students' opinion that the strategy used was good, easy to understand, fun and not easy to bore. As well as students who have attended learning by using strategi tulis kini were well.

\section{CONCLUSION}

Based on the results of the research and discussion, it could be concluded as follows: (1) The use of Strategi Tulis Kini, in lesson writing free poetry could be concluded that the teacher was good at using Strategi Tulis Kini, it could support the students to be more enthusiastic in writing poetry, and students have participated in learning by using Strategi Tulis Kini were very well, (2) Improving the learning outcomes of students' writing skills by using Strategi Tulis Kini was good because there was an increase in the average score of cycle I and II was 6.46, which was from 64.22 in the first cycle and 70.68 in the second cycle. The researcher concluded that learning by using Strategi Tulis Kini, improved the students' ability in writing free poetry, and (3) Student responses to Strategi Tulis Kini, based on the results of interviews obtained that the strategy used was good, easy to understand, fun and not easy to make students 
bored. Researchers concluded that the response of students in accepting learning by using Strategi Tulis Kini, was very good.

There are several suggestions conveyed by the researchers as follows: (1) It is expected that students will always be enthusiastic during the learning process, pay attention, ask questions, answer questions and play an active role in learning. Because it is very important to enrich knowledge during the teaching and learning process, (2) It is expected that the teachers always dig up information about the new learning method or model, so that the learning process conditions are always fun and produce quality students from all aspects, and suggested that the teachers apply writing strategy now, they have to look at the condition of the students at the first, whether it is in accordance with all the processes that exist in the current writing strategy, So that the learning process will run well later and the material studied will be easily understood by students, (3) Research results this can be used as one of sources in an effort to provide input to the teacher regarding the implementation of Strategi Tulis Kini, (4) It is recommended for researchers who are interested in researching more about Strategi Tulis Kini, paying more attention to the condition of students and facilities and infrastructure in schools, researchers do not have to see the environment around the school whether it would be suitable to use Strategi Tulis Kini,then the teachers must really pay attention to the learning devices and understand each stages in the learning device (RPP). Research with Strategi Tulis Kini, can also be used to improve learning activities, critical thinking skills and students' psychological knowledge.

\section{REFERENCES}

Emzir dan Roman Saifur.(2015). “Teori dan Pengajaran Sastra”. Jakarta:Rajawali Pers.

Hamzah. 2016. "Profesi Kependidikan" Jakarta:Bumi Aksara.

Nurgiyantoro,Burhan.2012. Penilaian Pembelajaran Bahasa BerbasisKompetensi. Yogyakarta: Anggota IKAPI.

Pradopo, Rachmat Djoko. 2012. "Pengkajian Puisi (Analisis Strata Norma dan Analisis Struktural dan Semiotik”. Yogyakarta: Gadjah Mada University Press.Maswins. 2011.

Silberman, Melvin. 2016. Active Learning: 101 Pembelajaran Aktif. Yogyakarta: Pustaka Intan Madani.

Sugiyono. 2008. Metode Penelitian Kuantitatif Kualitatif dan R\&D. Bandung: CV. Alfabeta. 